\title{
Can geometric morphometrics work for species clusteriza- tion on the armored catfish Hypostomus Lacépède, 1803 (Siluriformes Loricariidae)?
}

\author{
Francisco de Menezes Cavalcante Sassi', Manolo Fernandes Perez', Marcos Aurélio da Silva², Karine Frehner \\ Kavalco 3 \& Rubens Pasa ${ }^{3}$ \\ ${ }^{1}$ Laboratório de Citogenética de Peixes, Universidade Federal de São Carlos (UFSCar), Rodovia Washington Luis, \\ km 235, São Carlos - SP, Brazil \\ ${ }^{2}$ Salzburger Lab, University of Basel, Zoological Institute, Vesalgasse 1, Basel, Switzerland \\ ${ }^{3}$ Laboratório de Genética Ecológica e Evolutiva, Universidade Federal de Viçosa (UFV) Campus Rio Paranaíba, BR \\ 354, km 310, Rio Paranaíba, MG, Brazil \\ ${ }^{*}$ Corresponding author
}

\begin{abstract}
Studies with geometric morphometrics are efficient to clusterize and delimitate fish species. The armored catfish family (Loricariidae) is the second with more species and the Hypostomus genus can be highlighted as the most representative. By that, we present a geometric morphometric analysis in seven Hypostomus species from Paranaíba river basin (Brazil), testing which view for this technique were able to clusterize more efficiently the species. We found that lateral, frontal and ventral views were capable to form species-clusters with few overlaps in the PCA analysis. With the dorsal view overlapping all species, except for Hypostomus nigromaculatus, we consider that this view cannot be used for the geometric morphometric analysis. Hypostomus presents a complex taxonomy, with several cryptic species, and geometric morphometrics can be used as a complementary tool on Hypostomus taxonomy. Therefore, further analyses were required to evaluate the contribution of each landmark in species clusterization.
\end{abstract}

KEY WORDS Morphological evolution; Landmarks; Procrustes superimposition.

Received 18.08.2020; accepted 17.11.2020; published online 15.02.2021

\section{INTRODUCTION}

Fishes are aquatic organisms that present the biggest diversity of all vertebrates (Heule et al., 2014). Among the families distributed in Neotropical region, Loricariidae stands out as the second largest in species richness, encompassing seven subfamilies of about 70 genera and more than 1000 species (Nelson et al., 2016; Fricke et al., 2020). The Hypostominae subfamily composes the biggest partition of this richness, with 486 valid species (Fricke et al., 2020). In this subfamily, Hypostomus
Lacépède, 1803 is the most representative genus of the family, with around 130 species (Zawadzki et al., 2013) distributed throughout all Neotropical region (Fricke et al., 2020). This genus presents a complex level of species-taxonomy, being hampered by the high morphological variation found in local population, so as the presence of several cryptic species with major variation in morphology (Dias \& Zawadzki, 2018).

In the delimitation of morphologically challenging species, quantitative morphometric analysis has been shown to be at least as accurate as molecular 
analysis, and possibly more so (Lumley \& Sperling, 2010). Morphometry is the study of corporal variation and its covariation with other variables (Dryden \& Mardia, 1998). Based on that premise, geometric morphometrics (GM) arrived in 1990's and aims to elucidate the information present in the covariation between landmarks, which are the homologous points of interest that construct a shape (Rohlf \& Marcus, 1993).

Geometric morphometrics is efficient to cluster species and as a helpful tool on taxonomy (Mutanen \& Pretorius, 2007; Schwarzfeld \& Sperling, 2014; da Silva et al., 2020). Since Hypostomus fishes have a complex taxonomy and a high level of morphological variation, we develop a study aiming to:

i) determine which are the best view to clusterize the species of Hypostomus genus;

ii) discuss the variation of shapes based on the ecological aspects of Hypostomus fishes.

\section{MATERIAL AND METHODS}

\section{Samples obtainment and geometric morpho- metrics}

Between 2008 and 2017, in streams of Paranaiba river basin (Table 1), 97 samples of nine species were collected, identified and deposited in Vertebrates Collection of Federal University of Viçosa, Campus Rio Paranaíba. These species are: 16 Hy- postomus ancistroides (R. Ihering, 1911), $6 \mathrm{H}$. tietensis ( $\mathrm{R}$. Ihering, 1905), 19 H. regani $(\mathrm{R}$. Ihering, 1905), 3 H. commersoni Valenciennes, 1836, 3 H. strigaticeps (Regan, 1908), $3 \mathrm{H}$. paulinus (R. Ihering, 1905), 38 H. iheringii (Regan, 1908), 5 H. myersi (Gosline, 1947), 4 H. nigromaculatus (Schubart, 1964).

Specimens were photographed two times in four views (frontal, dorsal, ventral and lateral) with a Sony Cyber-Shot 14.1 megapixels camera, for the geometric morphometrics analysis. To group the images, TPSUtil 1.6 software (Rohlf, 2015) was used, followed by detection of landmarks (Figs. 18) on TPSDig 2.26 (Rohlf, 2015). The eight generated matrices (two for each view) were reduced to four, by calculating the mean for each view. Procrustes superposition was done with PAST 2.17 (Hammer et al., 2001), to minimize differences in translation, scaling and rotation between landmarks (Zelditch et al., 2012).

\section{Statistical analysis}

A Principal Coordinated Analysis (PCA) was performed in the R-package Morphotools (Koutecký, 2015) for each view separately, using the Procrustes transformed values. We plotted the contribution of each landmark for the two first principal axes. To avoid overfitting, we selected the lowest number of principal coordinate axes that ensure at least $90 \%$ of the variance were present in the

\begin{tabular}{|c|c|c|c|}
\hline Geographic region & Sampling site & Latitude & Longitude \\
\hline Aloândia - GO & Rio Meia-Ponte & $17^{\circ} 44^{\prime} 12.85^{\prime \prime S}$ & $49^{\circ} 25^{\prime} 52.55^{\prime \prime} \mathrm{W}$ \\
\hline Campos Altos - MG & Ribeirão do Quilombo Ponto 1 & $19^{\circ} 28^{\prime} 3.79^{\prime \prime S}$ & $46^{\circ} 17^{\prime} 32.33^{\prime \prime W}$ \\
\hline Carmo do Paranaíba - MG & Córrego de Carmo do Paranaíba & $19^{\circ} 1 ' 25.35^{\prime \prime S}$ & $46^{\circ} 23^{\prime} 20.96^{\prime \prime} \mathrm{W}$ \\
\hline Ibiá - MG & Ribeirão do Quilombo Ponto 2 & $19^{\circ} 29^{\prime} 38.88^{\prime \prime S}$ & $46^{\circ} 19^{\prime} 53.88^{\prime \prime} \mathrm{W}$ \\
\hline Monte Alegre de Minas - MG & Rio Tijuco & $19^{\circ} 2 ' 21.67^{\prime \prime S}$ & $49^{\circ} 0^{\prime} 31.17^{\prime \prime W}$ \\
\hline Patos de Minas - MG & Rio Paranaíba Ponto 3 & $18^{\circ} 40^{\prime} 0.51 " \mathrm{~S}$ & $46^{\circ} 31^{\prime} 13.12^{\prime \prime} \mathrm{W}$ \\
\hline Rio Paranaíba - MG & Córrego Água Grande & $19^{\circ} 12^{\prime} 17.25^{\prime \prime S}$ & $46^{\circ} 11^{\prime} 6.76^{\prime \prime} \mathrm{W}$ \\
\hline Rio Paranaíba - MG & Córrego dos Cascudos & $19^{\circ} 10^{\prime} 6.59^{\prime \prime} \mathrm{S}$ & $46^{\circ} 16^{\prime} 8.95^{\prime \prime} \mathrm{W}$ \\
\hline Rio Paranaíba - MG & Córrego São João & $19^{\circ} 16^{\prime} 35.11 " \mathrm{~S}$ & $46^{\circ} 16^{\prime} 22.81^{\prime \prime W}$ \\
\hline Rio Paranaíba - MG & Rio Paranaíba Ponto 1 & $19^{\circ} 10^{\prime} 55.68^{\prime \prime S}$ & $46^{\circ} 19^{\prime} 57.60^{\prime \prime} \mathrm{W}$ \\
\hline Rio Paranaíba - MG & Rio Paranaíba Ponto 2 & $19^{\circ} 4^{\prime} 32.08^{\prime \prime S}$ & $46^{\circ} 24^{\prime} 33.07^{\prime \prime W}$ \\
\hline Serra do Salitre $-\mathrm{MG}$ & Rio Paranaíba Ponto 5 & $18^{\circ} 55^{\prime} 4.26^{\prime \prime} \mathrm{S}$ & $46^{\circ} 30^{\prime} 20.68^{\prime \prime} \mathrm{W}$ \\
\hline Uberlândia - MG & Rio Uberabinha & $18^{\circ} 40^{\prime} 40.37 " \mathrm{~S}$ & $48^{\circ} 30^{\prime} 23.44^{\prime \prime} \mathrm{W}$ \\
\hline
\end{tabular}

Table 1. Geographic coordinates of Hypostomus sampling points in Paranaiba river basin - Brazil. 

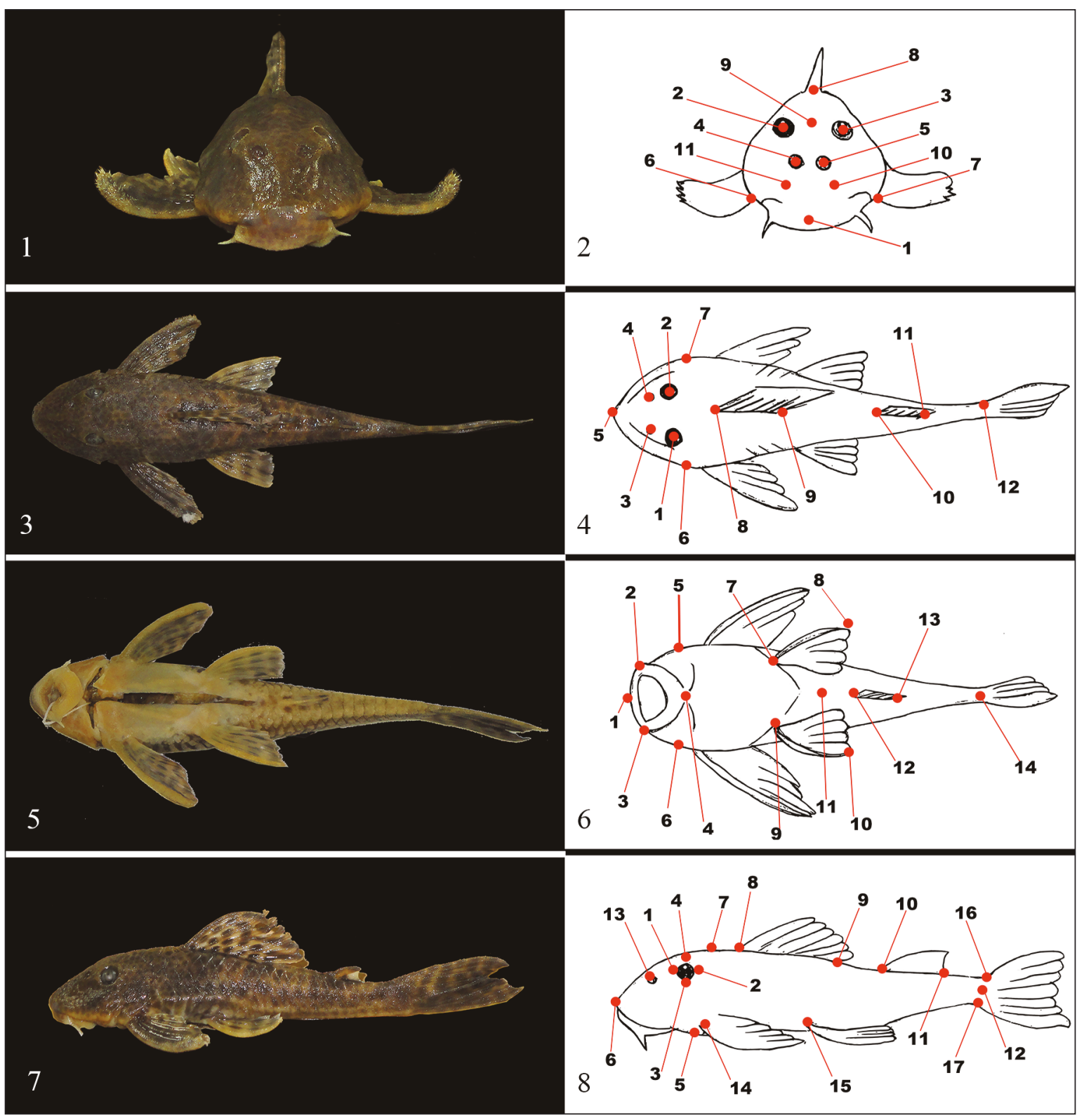

Figures 1-8. Photographs of an Hypostomus fish in four views: frontal (Figs. 1, 2), dorsal (Figs. 3, 4), ventral (Figs. 5, 6), and lateral (Figs. 7, 8). Schematic drawing representing the landmarks (in red) for each view. For the frontal view (Figs. 1, 2), we analyze the following landmarks: 1 - snout; 2 - right eye; 3 - left eye; 4 - right nostril; 5 - left nostril; 6 - right end of the head; 7 - left end of the head; 8 - dorsal fin insertion; 9 - central region between the eyes; 10 - bone beneath the left nostril; 11 - bone beneath the right nostril. On the dorsal view (Figs. 3, 4), the following landmarks were selected: 1 left eye; 2 - right eye; 3 - left nostril; 4 - right nostril; 5 - snout; 6 - left operculum; 7 - right operculum; 8 - dorsal fin insertion; 9 - dorsal fin end; 10 - adipose fin insertion; 11 - adipose fin end; 12 - caudal fin insertion. For the ventral view (Figs. 5, 6): 1 - snout; 2 - left side of the mouth; 3 - right side of the mouth; 4 - down-side of the lip; 5 - left operculum; 6 - right operculum; 7 - left pelvic fin insertion; 8 - left pelvic fin end; 9 - right pelvic fin insertion; 10 - right pelvic fin end; 11 - anus; 12 - anal fin insertion; 13 - anal fin end; 14 - caudal fin insertion. Finally, for the lateral view (Figs. 7, 8), the following landmarks were selected: 1 - left side of the eye; 2 - right side of the eye; 3 - downside of the eye; 4 - upside of the eye; 5 - operculum; 6 - snout; 7 - end of the head; 8 - dorsal fin insertion; 9 - dorsal fin end; 10 - adipose fin insertion; 11 - adipose fin end; 12 - center of caudal fin insertion; 13 - nostril; 14 - pectoral fin insertion; 15 - pelvic fin insertion; 16 - upside of caudal fin insertion; 17 - downside of caudal fin insertion. The landmarks were named to identify them on the analysis and does not correspond to the real names of the structures. 
data. The selected axes were then used to scatterplot the analyzed samples.

To test the capacity of Geometric Morphometrics to correctly reassemble the indicated species, we evaluate the capacity of the landmarks from each view to be assigned to the indicated species with a Linear Discriminant Analysis (LDA), performed with the package MASS in the R environment. To achieve this, we firstly performed an LDA informing the species identity. The obtained discriminants were then used to predict the species identity for each sample, using the leave-one-out cross-validation procedure.

\section{RESULTS}

After analyzing the contribution of each axis, we selected the 12,12, 13 and 13 principal coordinates for the dorsal, frontal, lateral and ventral view, respectively. Despite these small overlaps in all four views, each species was correctly reassigned by the LDA analysis.

In the lateral view (Fig. 9), the scatterplot of PCA presents a tendency of clusterization, with overlaps in Hypostomus regani, H. paulinus and $H$. ancistroides. Similarly, the frontal view (Fig. 10) also presents an overlap in $H$. ancistroides and $H$. regani, so as the ventral view (Fig. 11). On other hand, the PCA in dorsal view (Fig. 12) was not capable to create clusters in almost all species, with an exception to $H$. nigromaculatus.

\section{DISCUSSION}

The species clusterization by the PCA analysis in the lateral, frontal and ventral view, and the correctly reassignment with the LDA, indicates that geometric morphometrics could be a helpful tool in species clusterization on Hypostomus genus. In fact, Hypostomus presents a high morphological variation and presence of a very complex taxonomy in species level (Dias \& Zawadzki, 2018), highlighting the importance of this study.

The high diversity found in the Paranaíba river basin reflects the high capacity of Hypostomus fishes to explore several niches. This genus is classified as omnivorous, showing the plasticity of feed-habits, without the selection of food ingested
(Delariva \& Agostinho, 2001). This allows these organisms to inhabit rivers of various sizes and with variations in the amount of organic matter available. In addition to the food aspect, Hypostomus fishes can breathe atmospheric air, which guarantees them great resistance to environmental impacts or hypoxia conditions (Val \& Almeida-Val, 1995; Armbruster 1998).

Even with high diversity, the Hypostomus genus and this subfamily, Hypostominae, are still with an undefined status on phylogenetic classifications (Pinna, 1998). Montoya-Burgos (2003) identify monophyletic clades, but the group maintained the paraphyletic status. This can be attributed to the great morphological variation found in the group, which makes the visual identification based on external morphology complex, but possible when parsing key-characters.

As the body configuration may directly reflect the animal's habit, fishes with similar body height can be presented overlapped in PCA analysis. This seems to be the case of the repetitive overlap of $H$. regani and $H$. ancistroides, that have a similar body height, which gives them a greater hydrodynamic capacity (Breda et al., 2008).

The results of LDA shows that all views can reassign all species, indicating that these landmarks used on geometric morphometrics can predict species identity. Landmarks as indicators for species identity were used for several groups as Caucasian rock lizards Darevskia sp., where the tridimensional shape of the head is enough to separate close-related species by geometric morphometrics (Gabelaia et al., 2018). Plants (Chitwood \& Otoni, 2017) and insects (Villemant et al., 2007) were also used as model-organisms in geometric morphometrics studies that evaluate the biodiversity.

Geometric morphometrics had never been applied to Hypostomus genus, only for related genera such as Ancistrus Kner, 1854 (Reis et al., 2006). In this paper, the authors compare the shape of cavernous and epigean populations of Ancistrus species. They observe a morphological variation due to the presence of waterfalls in the course of the rivers, that creates topographic isolation. Otocinclus was also studied by geometric morphometrics, where Schaefer (1998) confirms the status of separated species in O. mariae Fowler, 1940 and $O$. vittatus Regan, 1904, O. bororo Schaefer, 1997 and O. huaroani Schaefer, 1997. 
Studies with geometric morphometrics are important for discrimination of species complexes (Fernando \& Walter, 1997), highlighting this paper. Despite this, even the most cautious analysis may be inconclusive, given the poor separation of groups or the lack of information on their biology (Baylack et al., 2003). In addition to the application with landmarks, other methods can be used to aid in the elucidation of diversity (Rohlf \& Archie, 1984; Loy et al., 2000), especially when testing the morphological difference between different habitats (Jonsson \& Jonsson, 2001). For the species complex of neotropical tetras Astyanax bimaculatus, A. fascia- tus and A. scabrippinis, for example, geometric morphometrics were able to identify a variation between two major groups, with both been related to the body height and thus to hydrodynamic capacity (da Silva et al., 2020).

In marine fishes, geometric morphometrics of scales was used for species delimitation in Mugilidae family (Ibañez et al., 2007). Geometric morphometrics was better to discriminate populations more geographically dispersed, species and genera than populations from closer areas (Ibañez et al., 2007). Geometric morphometrics is also effective to correlate habits and form in freshwater fishes,
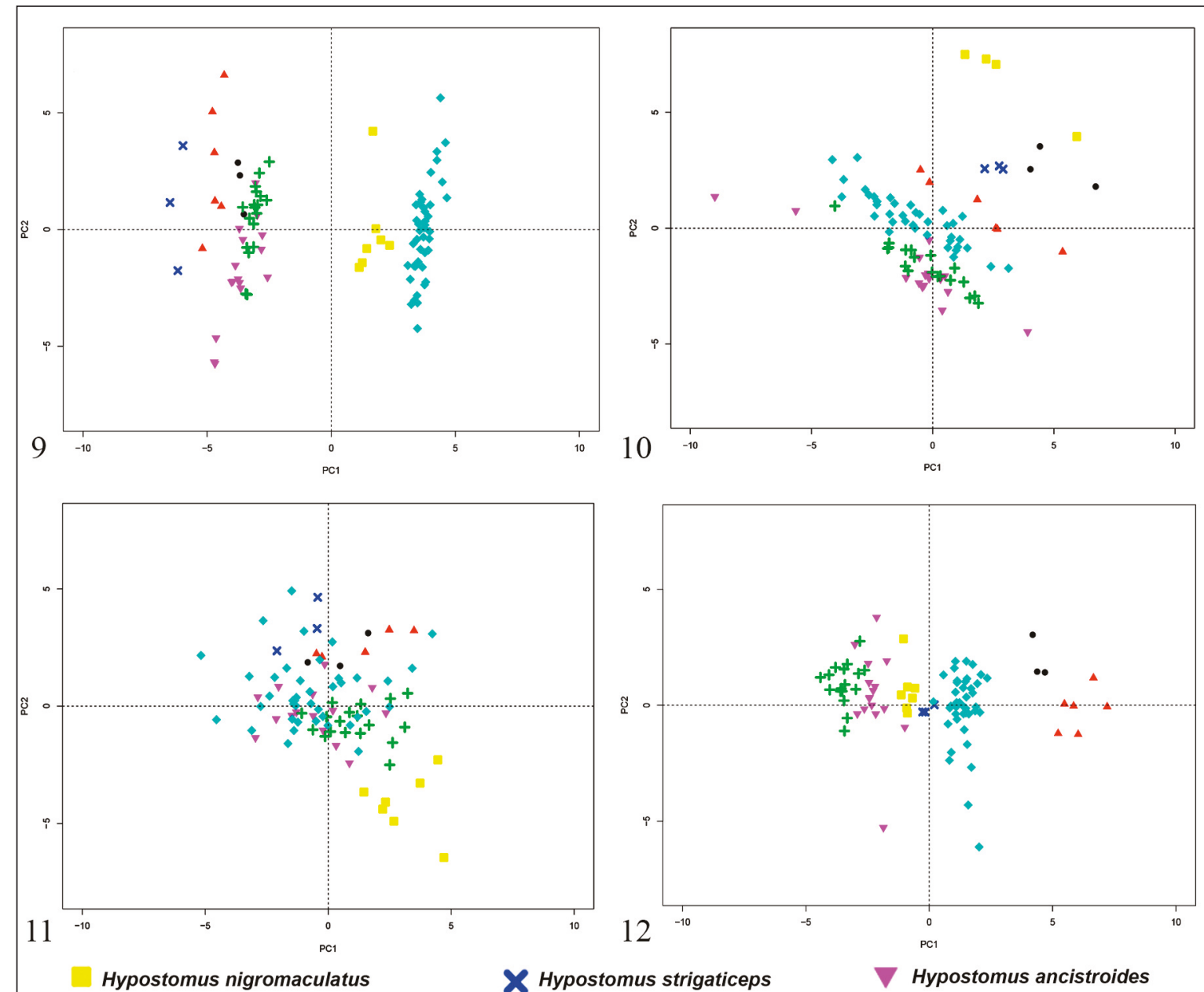

t Hypostomus regani

Hypostomus paulinus

Hypostomus tietensis

Hypostomus iheringii

Figures 9-12. Scatterplot of Principal Component Analysis (PCA) for each view. Each color/geometric shape corresponds to a species, respectively assigned in the figure. These analyses were performed separately for the lateral (Fig. 9), frontal (Fig. 10), ventral (Fig. 11) and dorsal (Fig. 12) view. 
like the cichlids of East Africa, that presents a body shape that can be most strongly predicted by feeding preferences and depth of occurrence in water (Clabaut et al., 2007).

Thus, we can conclude that lateral, frontal and ventral views was shown to be the highly effective for the species clusterization in geometric morphometrics analysis on Hypostomus genus, and other visions, such as dorsal, may be ruled out. Geometric morphometrics can be used as a helpful tool for delimitation and clusterization in fish groups. However, more studies are required to investigate the characters that most vary from species to species, which may contribute to shaping variation studies.

\section{ACKNOWLEDGEMENTS}

This study was financed in part by the Coordenação de Aperfeiçoamento de Pessoal de Nível Superior Brasil (CAPES) - Finance Code 001, Conselho Nacional de Pesquisa Científica e Tecnológica (CNPq), Fundação de Amparo à Pesquisa do Estado de Minas Gerais (FAPEMIG), Fundação de Amparo à Pesquisa do Estado de São Paulo (FAPESP) and also with personal financing by authors Rubens Pasa and Karine Frehner Kavalco. We also appreciate the contribution of Gabriela de Oliveira Garcia, Igor Henrique Rodrigues Oliveira, Iuri Batista da Silva, Larissa Elias Fernandes de Freitas, Matheus Lewi Cruz Bonaccorsi de Campos, Matheus de Oliveira Lunardi Laureano, Pierre Rafael Penteado, Rafael Pereira Silva, Rafaella Oliveira Lucas, Renan Rodrigues Rocha, Rosana de Mesquita Alves, Snaydia Viegas Resende, Winston Kleber Rodrigues and Willian Lopes Rocha for their assistance in material collection. Additionally, we also thank Vitor Augusto Rezende dos Santos, who helped to retrieve the samples and the names of people who assisted in the process. Finally, we want to thank Renata Rosa de Moraes who draw the schematic representation of landmarks.

\section{REFERENCES}

Armbruster J.W., 1998. Phylogenetic relationships of the suckermouth armored catfishes of the Rhinelepis group (Loricariidae: Hypostominae). Copeia: 620636.
Baylac M., Villemant C. \& Simbolotti G., 2003. Combining geometric morphometrics with pattern recognition for the investigation of species complexes. Biological Journal of the Linnean Society, 80: 89-98. https://doi.org/10.1046/j.1095-8312.2003.00221.x

Böhlke J.E., Weitzman S.H. \& Menezes N.A., 1978. Estado atual da sistemática dos peixes de água doce da América do Sul. Acta Amazonica, 8: 657-677.

Breda L., de Oliveira E.F. \& Goulart E., 2008. Ecomorfologia de locomoção de peixes com enfoque para espécies neotropicais. Acta Scientiarum Biological Sciences, 27: 371-381. https://doi.org/10.4025/actascibiolsci.v27i4.1271

Chitwood D.H., Otoni W.C., 2017. Morphometric analysis of Passiflora leaves: the relationship between landmarks of the vasculature and elliptical Fourier descriptors of the blade. GigaScience 6:giw008.

Clabaut C., Bunje P.M., Salzburger W. \& Meyer A., 2007. Geometric morphometric analyses provide evidence for the adaptive character of the Tanganyikan cichlid fish radiations. Evolution, 61: 560-578. https://doi.org/10.1111/j.1558-5646.2007.00045.x

Delariva R.L., Agostinho A.A., 2001. Relationship between morphology and diets of six neotropical loricariids. Journal Fish Biology, 58: 832-847. https:// doi.org/10.1111/j.1095-8649.2001.tb00534.x

Dias A.C., Zawadzki C.H., 2018. Identification key and pictures of the Hypostomus Lacépède, 1803 (Siluriformes, Loricariidae) from the rio Ivaí, upper rio Paraná basin. Check List 14: 393.

Dryden I.L. \& Mardia K.V., 1998. Statistical analysis of shape. Wiley Library, Chichester, 347pp.

Fernando L.C.P. \& Walter G.H., 1997. Species status of two host-associated populations of Aphytis lingnanensis (Hymenoptera: Aphelinidae) in citrus. Bulletin of Entomological Research, 87: 137-144.

Fricke R., Eschmeyer W.N., van der Laan R., 2020. Eschmeyer's Catalog of Fishes: Genera, Species, References.http://researcharchive.calacademy.org/resear ch/ichthyology/catalog/fishcatmain.asp. Electronic version accessed 25 July 2020.

Gabelaia M., Tarkhnishvili D. \& Adriaens D., 2018. Use of three-dimensional geometric morphometrics for the identification of closely related species of Caucasian rock lizards (Lacertidae: Darevskia). Biological Journal of the Linnean Society, 125: 709-717. http://hdl.handle.net/1854/LU-8576825

Hammer Ø., Harper D.A.T. \& Ryan P.D., 2001. PAST: Paleontological Statistics Software Package for Education and Data Analysis. Palaeontologia Electronica, 4: 9.

Heule C., Salzburger W. \& Böhne A., 2014. Genetics of sexual development: an evolutionary playground for fish. Genetics, 196: 579-591. https://doi.org/10.1534/ genetics.114.161158 
Ibañez A.L., Cowx I.G. \& O’higgins P., 2007. Geometric morphometric analysis of fish scales for identifying genera, species, and local populations within the Mugilidae. Canadian Journal of Fisheries and Aquatic Sciences, 64: 1091-1100. https://doi.org/10. 1139/F07-075

Jonsson B. \& Jonsson N., 2001. Polymorphism and speciation in Arctic charr. Journal of Fish Biology, 58: 605-638.

Koutecký P., 2015. MorphoTools: a set of R functions for morphometric analysis. Plant Systematics and Evolution, 301: 1115-1121. https://doi.org/10.1007/ s00606-014-1153-2

Lowe-McConnell R.H., 1999. Estudos ecológicos de comunidades de peixes tropicais. In Coleção Base. Edusp.

Loy A., Busilacchi S., Costa C., Ferlin L. \& Cataudella S., 2000. Comparing geometric morphometrics and outline fitting methods to monitor fish shape variability of Diplodus puntazzo (Teleostea: Sparidae). Aquacultural Engineering, 21: 271-283.

Lumley L.M. \& Sperling F.A., 2010. Integrating morphology and mitochondrial DNA for species delimitation within the spruce budworm (Choristoneura fumiferana) cryptic species complex (Lepidoptera: Tortricidae). Systematic Entomology, 35: 416-428. https://doi.org/10.1111/j.1365-3113.2009.00514.x

Montoya-Burgos J.I., 2003. Historical biogeography of the catfish genus Hypostomus (Siluriformes: Loricariidae), with implications on the diversification of Neotropical ichthyofauna. Molecular Ecology, 12: 1855-1867. https://doi.org/10.1046/j.1365-294X. 2003.01857.x

Mutanen M. \& Pretorius E., 2007. Subjective visual evaluation vs. traditional and geometric morphometrics in species delimitation: a comparison of moth genitalia. Systematic Entomology, 32: 371-386. https:// doi.org/10.1111/j.1365-3113.2006.00372.x

Nelson J.S., Grande T.C. \& Wilson M.V., 2016. Fishes of the World. John Wiley \& Sons.

Pinna M., 1998. Phylogenetic Relationships of Neotropical Siluriformes (Teleostei: Ostariophysi): Historical Overview and Synthesis of Hypotheses. In: Malabarba L., Reis R., Vari R., Lucena Z., Lucena C., Phylogeny and Classification of Neotropical Fishes, Porto Alegre, pp. 279-330.

Reis R.E., Trajano E. \& Hingst-Zaher E., 2006. Shape variation in surface and cave populations of the armoured catfishes Ancistrus (Siluriformes: Loricari- idae) from the Sao Domingos karst area, upper Tocantins River, Brazil. Journal of Fish Biology, 68: 414-429.

Rohlf F.J. \& Archie J.W., 1984. A comparison of Fourier methods for the description of wing shape in mosquitoes (Diptera: Culicidae). Systematic Zoology, 33: 302-317.

Rohlf F.J. \& Marcus L.F., 1993. A revolution morphometrics. Trends in Ecology \& Evolution, 8: 129-132.

Rohlf F.J., 2015. The tps series of software. Hystrix 26: 9-12.

Schaefer S.A., 1998. The neotropical cascudinhos: systematics and biogeography of the Otocinclus catfishes (Siluriformes: Loricariidae). Proceedings of the Academy of Natural Sciences of Philadelphia, 148: $1-120$

Schwarzfeld M.D. \& Sperling F.A., 2014. Species delimitation using morphology, morphometrics, and molecules: definition of the Ophion scutellaris Thomson species group, with descriptions of six new species (Hymenoptera, Ichneumonidae). Zookeys, 462: 59. https://doi.org/10.3897/zookeys.462.8229

da Silva M.A., Perazzo G.X., Kavalco K.F. \& Pasa R., 2020. Shape diversity of the fish genus Astyanax Baird \& Girard, 1854 (Teleostei, Characidae) in adjacent basins. Biologia. https://doi.org/10.2478/ s11756-020-00544-5

Val A.L. \& Almeida-Val V.M.F., 1995. Fishes of the Amazon and their environment: physiological and biochemical aspect. New York: Springer-Verlag, 224 pp.

Vari R.P. \& Malabarba L.R., 1998. Neotropical ichthyology: an overview. Phylogeny and classification of Neotropical fishes, 1: 1-12.

Villemant C., Simbolotti G. \& Kenis M., 2007. Discrimination of Eubazus (Hymenoptera, Braconidae) sibling species using geometric morphometrics analysis of wing venation. Systematic Entomology, 32: 625634. https://doi.org/10.1111/j.1365-3113.2007.003 89.x

Zawadzki C.H., Oliveira R.R.D. \& Debona T., 2013. A new species of Hypostomus Lacépède, 1803 (Siluriformes: Loricariidae) from the rio TocantinsAraguaia basin, Brazil. Neotropical Ichthyology, 11: 73-80. https://doi.org/10.1590/S1679-62252013000 100008

Zelditch M.L., Swiderski D.L. \& Sheets H.D., 2012. Geometric morphometrics for biologists: a primer. Academic Press. 
. 